\title{
The Plan of the Selected Location of the Dynamic Alliance Store Centre and the Example Analysis
}

\section{Zhimei ZHOU}

Faculty of Logistics Engineering, WuHan University of Technology, WuHan, China

Hong PENG

WuHan Institute of Technology, WuHan, China

ABSTRACT: The agile virtual enterprise sets up the distribution centre and store centre of dynamic alliance. It's the important way that realizes the supply chain "the agility". It is discussed in this paper. This paper reseaches to use the precise centroid method and linear plan model to carry on the selected location modelling for the store centre of the dynamic alliance and example analysis. Its aim is to set up the agility of the supply chain.

KEYWORD: Dynamic alliance; The plan of the selected location of the dynamic alliance store centre; Linear plan model

\section{INTRODUCTION}

The supply chain operation of the dynamic alliance is the one of important factors effect on competitive power of the market[1]. Highly effective, agile supply chain management pattern will guarantee the raw material to supply and product going on the market promptly, and will cause the enterprise to seize the market to take the initiative[2], it has the competitive advantage, enable the customer to obtain the order product promptly, and makes the customer satisfaction.

The agile virtual enterprise sets up the distribution centre and store centre of dynamic alliance. It's the important way that realizes the supply chain "the agility";

This article introduces two methods commonly used of the dynamic alliance store center selected location [3].

\section{THE PLAN OF THE SELECTED LOCATION OF THE DYNAMIC ALLIANCE STORE CENTRE AND THE EXAMPLE ANALYSIS}

\subsection{The model of the selected location of the dynamic alliance store centre decision-making and the example analysis}

\subsubsection{The precise centroid method}

Besides consideration above factors, this article uses the selected location model of continuous point precise centroid model, carries on the selected location plan to the Wuhan XinHua Bookstore logistics department alliance store center, it has used the OuJi-Meader distances, that is the straight distance, caused the selected location to become precise, and it has the broader application scope.

Carries on the description using the mathematical linguistics to be as follows:

Objective function:

$$
\min Z=\sum_{i=1}^{n} f_{i}\left[\left(\mathrm{x}_{\mathrm{i}}-\mathrm{x}_{\mathrm{s}}\right)^{2}+\left(\mathrm{y}_{\mathrm{i}}-\mathrm{y}_{\mathrm{s}}\right)^{2}\right]^{1 / 2}
$$

This is a double variable system, separately seeks the partial differential to $\mathrm{x}_{\mathrm{s}}$ and $\mathrm{y}_{\mathrm{s}}$, and make it equal to zero, like this may obtain two differential equalities. Separately seeks the solution using these two equalities to $\mathrm{x}_{\mathrm{s}}$ and $\mathrm{y}_{\mathrm{s}}$, then extracts a following pair of concealment equality to have the optimal solution:

$$
\mathrm{x}_{\mathrm{s}}=\frac{\sum_{i=1}^{n}\left(\frac{f_{i} x_{i}}{d_{i s}}\right)}{\sum_{j=1}^{n}\left(\frac{f_{i}}{d_{i s}}\right)} ; \mathrm{y}_{\mathrm{s}}=\frac{\sum_{i=1}^{n}\left(\frac{f_{i} y_{i}}{d_{i s}}\right)}{\sum_{i=1}^{n}\left(\frac{f_{i}}{d_{i s}}\right)}
$$

Thus, $\mathrm{d}_{\mathrm{is}}=\left[\left(\mathrm{x}_{\mathrm{i}}-\mathrm{x}_{\mathrm{s}}\right)^{2}+\left(\mathrm{y}_{\mathrm{i}}-\mathrm{y}_{\mathrm{s}}\right)^{2}\right]^{1 / 2}$

Regarding this question, we may carry on the solution through the iterative method, needs to provide group of starting values $\mathrm{X}_{\mathrm{i}}$ and $\mathrm{Y}_{\mathrm{i}}$. Then uses $\mathrm{x}_{\mathrm{s}(\mathrm{i}-1)}$ and $\mathrm{y}_{\mathrm{s}(\mathrm{i}-1)}$ to extract $\mathrm{x}_{\mathrm{si}}$ and $\mathrm{y}_{\mathrm{si}}$ again, the iterative formula is as follows: 


$$
\begin{gathered}
\mathrm{x}_{\mathrm{s}} \frac{\sum_{i=1}^{n}\left(\frac{f_{i} x_{i}}{d_{i s(i-1)}}\right)}{\sum_{j=1}^{n}\left(\frac{f_{i}}{d_{i s(i-1)}}\right)} \\
\mathrm{y}_{\mathrm{s}}=\frac{\sum_{i=1}^{n}\left(\frac{f_{i} y_{i}}{d_{i s(i-1)}}\right)}{\sum_{i=1}^{n}\left(\frac{f_{i}}{d_{i s(i-1)}}\right)}
\end{gathered}
$$

Thus, $\mathrm{d}_{\mathrm{is}(\mathrm{i}-1)}=\left[\left(\mathrm{x}_{\mathrm{si}}-\mathrm{x}_{\mathrm{s}(\mathrm{i}-1)}\right)^{2}+\left(\mathrm{y}_{\mathrm{si}}-\mathrm{y}_{\mathrm{s}(\mathrm{i}-1)}\right)^{2}\right]^{1 / 2}$

If this repetitive process has astringency, after then passes through the non-time limit iteration, it may obtain an optimal solution $x_{i}$ and $y_{i}$. In reality, it is limited that may iterate times, therefore needs to determine a termination criterion in the iterative process. Mainly there are two methods:

One is: According to the experience and the former test results, we directly establish definite iterative times $\mathrm{N}$;

Two is: Nearby iterative result $\mathrm{x}_{\mathrm{si}}$ and $\mathrm{y}_{\mathrm{si}}$ which each time obtains a time iterative result $\mathrm{x}_{\mathrm{s}(\mathrm{i}-1)}$ and $\mathrm{y}_{\mathrm{s}(\mathrm{i}-1)}$, when two time iterative result change is smaller than some value $\Delta \mathrm{x}_{\text {slimit }}, \Delta \mathrm{y}_{\text {slimit, }}$ the iterative process will be ended. The expression is as follows:

$$
\begin{aligned}
& \Delta \mathrm{x}_{\mathrm{s}}=\left[\begin{array}{ll}
\mathrm{x}_{\mathrm{si}^{-}} & \mathrm{x}_{\mathrm{s}(\mathrm{i}-1)}
\end{array}\right] \leq \Delta \mathrm{x}_{\text {slimit }} \\
& \Delta \mathrm{y}_{\mathrm{s}}=\left[\begin{array}{ll}
\mathrm{y}_{\mathrm{si}^{-}} & \mathrm{y}_{\mathrm{s}(\mathrm{i}-1)}
\end{array}\right] \leq \Delta \mathrm{y}_{\text {slimit }}
\end{aligned}
$$

The optimal solution that the precise centroid model approach obtains is a spot. Also it need further revision in the practical application, Through analysis to the selected location plan of alliance store center question, we have established the related mathematical model, and taken one of the ways of realization dynamic alliance agile supply chain. In the article, the mathematical model which we establish unifies the continual model and the discrete model reduces the computation load in a certain extent, increases the computation precision. Certainly, also we have the insufficiency in very many places, further will consummate in the next work.

\subsubsection{Linear plan model}

Regarding the single facility selected location question, we may use the precise centroid model to seek solution. In order to ask the effective method of selected location question, we may attempt to use advanced management science technology to enrich the analysis method, to provide the improvement method that researches of the optimal solution. These methods including target programming law, shape of tree search method, dynamic programming law and the other means. Regarding the multifacility selected location question, for example, the selected location question that a logistics district it is equipped with many allocation center, and supplies many sale plot (or store) may be used the linear plan-transportation law to solve[4], it make the total transport expense of all facilities to be lowest, namely:

Object function: $\sum_{i=1}^{m} \sum_{j=1}^{n} c_{i j} x_{i j}$

$S=\left\{\begin{array}{l}\sum_{j=1}^{n} x_{i j}=a_{i} \\ \sum_{i=1}^{m} x_{i j}=b_{j}\end{array} x_{i j} \geq 0\right.$

In the formula,

$m$-- Distribution center number;

$n$-- Sale spot number;

$a_{i}$--The productivity of distribution center $i$

$$
(i=1,2,3, \ldots \mathrm{m}) \text {; }
$$

$b_{j}$-- The demand of Sale point $j(j=1,2,3 \ldots \mathrm{m})$;

$c_{i j}$-- Unit product made by in distribution center $i$;

$x_{i j}$--The product quantities from distribution center $i$

transportation to the sale point $j$.

\subsection{The selected location of the dynamic alliance store centre decision-making and the example analysis}

Below we take the selected location way of Wuhan XinHua Bookstore alliance store center of logistics department as the example, and elaborate the method of alliance store center selected location.

Wuhan XinHua Bookstore is the alliance enterprise which is composed by many branch stores. Because the store ability of each branch store is limited, it affects the daily operation sale of various shops, therefore we plan to select location to construct alliance store center in the Wuhan urban district, The following question has been considered in the selected location process;

Unifies the actual situation of Wuhan Wusheng Road XinHua Bookstore, selecting the location of the XinHua Bookstore alliance store center of logistics department, considers following factors in several aspects:

(1) First we considered the store center is located the position in the city: It is situated in science and technology district in the Hankou Huangpu road, this is a high new technology area which Wuhan Municipal government plans, the vast territory with a sparse population, there is advantageous for further develops.

(2)Transportation is convenient there, the staff may come and go to work by bus, they can rapid 
arrive each branch store conveniently. There is only 1 kilometer distance to host way entrance; The distance from Yangtze River second bridges is only 2 kilometers; and from WuHuang highway entrance is only 2 kilometers.

(3)The telephone channel is unobstructed, the power supply is sufficient.

(4)There is non-traffic controlling and planning, unlimited vehicle stipulation; There is cement road surface, and the state of roads is very good, the peripheral turnover channel opens access, the way which leaves and enters store is six traffic lanes, it is suitable for the mass carrier vehicle in and out.

(5) In technical district the safety and security measure are strict, there are the police station, the bank and the hospital in two kilometers. the measure which drains water and controls flood are strict.

Wuhan XinHua Bookstore is the alliance enterprise which is composed by many branch stores, the main branch store includes: Wusheng road XinHua Bookstore, QingShan XinHua Bookstore, Wuchang XinHua Bookstore, Hongshan XinHua Bookstore, Jianghan Road XinHua Bookstore, presently we respectively suppose to be F1, F2, F3, F4, F5.At present XinHua China Bookstore is using the store of the GuTian fourth load store and the Wusheng road store, now because each warehouse memory property is limited, it affects the daily operation sale of various shops.

Therefore we also need set up a warehouse center, we make the decision-making after comparison the HouHu logistics department and the Wusheng road store expense. According to the statistical data, after the analysis we obtain total expense from the GuTian fourth load store P1, Wusheng road store P2, alliance store center $\mathrm{P} 3$, the HouHu logistics department $\mathrm{P} 4$ to each sale point as shown in Table 1 , in which alliance store center P3 is located in the regions nearby Wuchang bridgehead of the Yangtze River second bridge, compared with alliance store center P3 and HouHu logistics department P4 expense, then we can the best position determine of warehouse center.

Table 1 supply and demand meter

\begin{tabular}{|c|c|c|c|c|c|c|}
\hline & $\mathrm{F} 1$ & $\mathrm{~F} 2$ & $\mathrm{~F} 3$ & $\mathrm{~F} 4$ & $\mathrm{~F} 5$ & $\begin{array}{c}\text { Supply/year } \\
\text { (ten } \\
\text { thousands }\end{array}$ \\
\hline $\mathrm{P} 1$ & 7.2 & 16.0 & 13.0 & 14.0 & 10.5 & 184 \\
\hline $\mathrm{P} 2$ & 0 & 14.8 & 11.8 & 12.8 & 9.2 & 200 \\
\hline $\mathrm{P} 3$ & 8.0 & 10.9 & 10.5 & 11.5 & 7.8 & 248 \\
\hline $\mathrm{P} 4$ & 7.8 & 11.2 & 10.8 & 11.8 & 7.5 & 232 \\
\hline $\begin{array}{c}\text { demand } \\
\text { (ten }\end{array}$ & 216 & 120 & 168 & 144 & 216 & 864 \\
thousands) & & & & & & \\
\hline
\end{tabular}

According to the above supply and demand meter, we may obtain following supply and demand distribution list, as Table 2, 3 show:

We suppose that new alliance warehousing center is located in P3, according to transportation question solution [5], we can obtain the supply and demand assignment table 2 , then the complete expense is at least:

\section{$\mathrm{S} 1=144 \times 12.8+120 \times 10.9+168 \times 10.5+64 \times 10.5+56 \times 9.2$ $+96 \times 8.0+96 \times 7.8+120 \times 7.2$ \\ $=8483.2($ ten thousands yuan}

Table 2 The supply and demand distribution list of store centers in $\mathrm{P} 3$ place

\begin{tabular}{|c|c|c|c|c|c|c|c|c|c|}
\hline $\begin{array}{l}\text { from } \\
\text { to }\end{array}$ & $\mathrm{F} 1$ & \multicolumn{2}{|l|}{ F2 } & \multicolumn{2}{|l|}{$\mathrm{F} 3$} & $\mathrm{~F} 4$ & \multicolumn{2}{|l|}{ F5 } & $\begin{array}{l}\text { Supply/year } \\
\text { thousands) }\end{array}$ \\
\hline \multirow[b]{2}{*}{ P1 } & (8). 7.2 & 。 & 16.0 & 0 & 13.0 & 14.0 & (4) & 10.5 & \multirow[t]{2}{*}{184} \\
\hline & 146 & & & & & & \multicolumn{2}{|l|}{38} & \\
\hline \multirow{2}{*}{ P2 } & 0 & \multirow[t]{2}{*}{3} & 14.8 & \multirow[t]{2}{*}{ o } & \multirow[t]{2}{*}{11.8} & (1). 12.8 & \multirow{2}{*}{\multicolumn{2}{|c|}{$\begin{array}{l}\text { (5) } \\
56\end{array}$}} & \multirow[t]{2}{*}{200} \\
\hline & e & & & & & 144 & & & \\
\hline \multirow{2}{*}{ P4 } & (6). 7.8 & (2) & 11.2 & (3) & 10.8 & 11.8 & \multirow{2}{*}{$\begin{array}{l}\text { (7) } \\
122\end{array}$} & \multirow[t]{2}{*}{7.5} & \multirow[t]{2}{*}{480} \\
\hline & 70 & \multicolumn{2}{|c|}{120} & \multicolumn{2}{|c|}{168} & & & & \\
\hline demand/year & \multirow[b]{2}{*}{216} & \multirow{2}{*}{\multicolumn{2}{|c|}{120}} & \multirow{2}{*}{\multicolumn{2}{|c|}{168}} & & \multirow{2}{*}{\multicolumn{2}{|c|}{216}} & \\
\hline $\begin{array}{c}\text { (ten } \\
\text { thousands) }\end{array}$ & & & & & & 144 & & & 864 \\
\hline
\end{tabular}

Table 3 The store centers in P4 place supply and demand distribution list

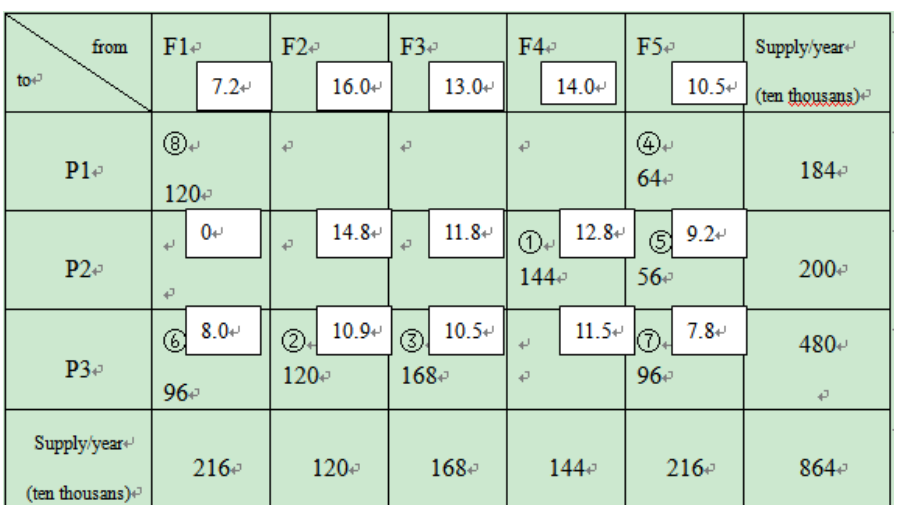

We suppose that new alliance warehousing center is located in $\mathrm{P} 4$, according to the transportation question solution, we can obtain the supply and demand distribution list 3 , then the complete expense is at least:

\section{$\mathrm{S} 2=144 \times 12.8+120 \times 11.2+168 \times 10.8+38 \times 10.5+56 \times 9.2$ $+70 \times 7.8+122 \times 7.5+146 \times 7.2$ \\ $=8427.2$ (ten thousands yuan)}

Comparison the above computed result, we may result in according to, Best selected location position of the Wuhan XinHua Bookstore alliance store center should be the region nearby Hankou bridgehead of the Yangtze River second bridge, now the Wuhan XinHua Bookstore logistics department store center is located in the HouHu nearby Hankou Huangpu road science and technology district, such selected location has many superiorities in 
geographical environments and economic environment, also may reduce the cartage expense to the lowest.

\section{THE END}

Regarding the alliance enterprise, the alliance store center selected location question is the question important, the strategic policy-making of alliance enterprise. The alliance store center address selection quality affects directly the efficiency of enterprise logistics system link. In entire supply chain angle, the alliance store center is the entire supply chain junction, it affects the product flows in direction and rate which in the chain flows, and plays the key role in the efficiency and service level of supply chain.

\section{REFERENCES}

[1] Inman R A, Sale R S, Green Jr K W, et al. Agile manufacturing: relation to JIT, operational performance and firm performance. Journal of Operations Management, 2011, 29(4): 343-355.

[2] YuFuMao, Research the some key problionems of the plan of the logistics system. Dr. Academic Dissertation of ZheJiang University.2003.

[3] ZhouZhiMei, Dynamic Logistics Planning and Simulation that Supports the Supply Chain agility of the Agile Virtual Enterprise. WuHan University of Tochnology. Dr.'s Academic Dissertation, 64-69.

[4] Cai Linning, Logistics system planning---Modelling and example analysis. Mechanical industry publishing company, 2003.

[5] Hu Liege, how ultra, Sheng Yu Kui. Logistics operational research. Beijing: Electronics industry publishing company, 2005. 